\title{
Schellenberg on propositional faith
}

\author{
DANIEL HOWARD-SNYDER \\ Department of Philosophy, Western Washington University, 515 High Street, Bellingham, \\ WA 98225, USA, Dan.Howard-Snyder@wwu.edu
}

\begin{abstract}
This paper assesses J. L. Schellenberg's account of propositional faith and, in light of that assessment, sketches an alternative that avoids certain objections and coheres better with Schellenberg's aims.
\end{abstract}

My topic is J. L. Schellenberg on propositional faith. ${ }^{1}$ In what follows, I will state his account and, in that sacred tradition among friends, develop three complaints about it. Finally, I'll sketch an alternative that avoids those complaints and coheres better with its primary aims.

Before I get down to work, three preliminaries are in order.

First, propositional faith is a propositional attitude expressed by typical uses of 'faith that p', where p takes declarative sentences as instances, e.g. 'She has faith that they'll work out their difficulties'. Whenever I speak of 'the object of faith' I will mean either the proposition or the state of affairs reported by it.

Second, we sometimes say things of the form 'S has faith in $\mathrm{x}$ ', where $\mathrm{x}$ takes a name of a person or some other entity as instances, as in 'She has faith in her husband'. Faith in something is relative to a specific domain. My wife has faith in me, as a friend and lover, not as a literary critic. I suspect that faith-that is not faith-in. For one to have faith in something is for one to entrust one's welfare to it in some way; however, one can have faith that something is thus-and-so without entrusting one's welfare to it or to its being thus-and-so. For example, I might have faith that Emily will survive breast cancer but I do not thereby entrust my welfare to her or to her survival.

Third, in what follows, I am only concerned with faith-that, not faith-in. Unless I state otherwise, whenever I use 'faith', I mean propositional faith.

\section{Schellenberg's account of propositional faith}

So what are Schellenberg's aims in giving an account of propositional faith? Chief among other things, (i) to show how faith does not require belief in its 
propositional object, (ii) to display how faith is at home with being in doubt about its object, and (iii) to exhibit how a religious agnostic might have faith in an epistemically responsible and epistemically virtuous fashion, one that can ground a religious way of life. I affirm each of these aims. In what follows I will be critical of Schellenberg's attempt to meet them, but I can't overemphasize that in sharing these aims, we are fellows over faith, not foes.

The best way to begin to engage Schellenberg's account is through one of the short stories he uses to illustrate it. Think of a runner, he writes,

who is considering whether he will do well in the important race that is about to begin. Loosening up and stretching behind the starting line, he broods about how on this day of all days his condition is not exactly favorable to success, because of various physical ailments. Going over the relevant evidence, which at first he is inclined to read very negatively, he notices that it does not establish that he must fail; on at least some occasions in the past he has done well when feeling unwell, and he knows of a few other runners who have clocked good times in such adverse conditions. But all in all the evidence on which he reflects still is insufficient to cause in him the belief that he will do well; it takes him from disbelief to doubt but no further. At this point he realizes that he will have to do something about his frame of mind if he is to have any chance of beating the odds. Winning the race, or at least placing in the top three, would obviously be a good thing; so he tells himself to contemplate that good thing for a bit. As he focuses his attention on it, the unsettling feelings associated with his doubt recede to the background; there is no longer room for them at the forefront of his consciousness. Keeping that picture before his mind as he positions himself with the other runners, he mentally affirms over and over that it corresponds to the way things are: "Yes, I will do well, yes, I will do well..." This pushes him forward into a new place, mentally speaking, one in which his doubt remains...but in which it is overlaid by an attitude of a very different kind toward the proposition that he will do well. ${ }^{2}$ 
Schellenberg specifies 'four elements' in this story, each of which are necessary, he says, and jointly sufficient for faith. First, the runner lacks evidence causally sufficient to believe that he will do well. Second, he considers the obtaining of the state of affairs reported by the proposition that he will do well to be good or desirable. Third, while warming up, he focuses his imagination on his doing well while, fourth, he repeatedly affirms by choice that this state of affairs 'corresponds to the way things are'.

Generalizing from this case and others like it, in addition to giving other lines of support, Schellenberg offers the following account:

$\mathrm{S}$ has faith that $\mathrm{p}$ if and only if (1) S lacks evidence causally sufficient to believe that $\mathrm{p}$, (2) $\mathrm{S}$ considers the state of affairs reported by $\mathrm{p}$ to be good or desirable, (3) $\mathrm{S}$ tenaciously and persistently represents the world to herself as including that state of affairs, and (4) S voluntarily and committedly adopts a policy of assent toward that representation - or, more broadly, toward $\mathrm{p}^{3}$

I have three complaints that come under three headings: faith and desire, faith and belief, and faith and doubt.

\section{Faith and desire}

After stating that faith requires one to consider the truth of its propositional object to be good or desirable, Schellenberg raises the question of whether one must have a 'pro-attitude' toward its truth as well. The answer, he says, depends

on how much one builds into that notion of a pro-attitude. Probably it would be viewed by most philosophers as involving not just a favorable opinion but also a strong enough approval of the truth of the proposition to entail a desire that the proposition be true - which takes us beyond what is essential to propositional faith. Something may intellectually be seen as desirable - as worthy of desire without actually being desired, when relevant psychological obstacles are present. And such may be the case when someone chooses to have faith. ${ }^{4}$ 
I agree that one can have faith that something is so only if one considers its truth to be good or desirable. And I agree that considering the truth of a proposition to be good or desirable is not the same thing as wanting it to be true. But is it all plausible, as Schellenberg claims, that one can have faith that something is so even though one has no desire at all for it to be true?

Schellenberg defends this claim by imagining himself to be a politician defeated in the primaries by a party rival and, now continuing in the voice of the politician,

being somewhat undeveloped emotionally - I feel a lot of resentment toward him and really do not want him to win; indeed, I harbor a strong secret desire that he'll lose. Nevertheless, whether from party loyalty or obligation...or because I want to achieve some benefit for myself, here I am, campaigning for him, and in a situation where - because of a protracted slump in the polls - I have to have faith that he will win if I am to project the needed positivity. ${ }^{5}$

What should we make of this case?

I find it unconvincing. If the politician really does project the needed positivity while having no desire at all that his rival win, then he's doing what politicians do best: faking it. More likely, he has conflicting desires. On the one hand, he wants his party rival to lose while, on the other hand, he wants his party to win; but he can't have it both ways.

No doubt, Schellenberg will have more to say in defence of his claim. What I want to consider here, however, is what might be said on behalf of its denial, that is, on behalf of the claim that one cannot have faith that something is so without also wanting it to be true, or wanting the state of affairs reported by it to obtain.

Here's an argument for it. You have faith that $\mathrm{p}$ only if you consider p's truth to be good or desirable, but you cannot consider p's truth to be good or desirable unless you want it to be the case that p; so you have faith that $\mathrm{p}$ only if you want it to be the case that p. To be sure, you might have conflicting desires; indeed, you might only want it a little bit. Nevertheless, you must want $p$ to be the case if you have faith that $p$. 
Many will deny the premise that you cannot consider p's truth to be good or desirable unless you want it to be the case that p. This isn't the place to enter that longstanding dispute. Let's grant the objection; still, three other arguments remain.

First: one has faith that $\mathrm{p}$ only if one cares that $\mathrm{p}$, but one cares that $\mathrm{p}$ only if one has some desire for p's truth. (Here and hereafter, I mean 'cares with positive valence that p'.) After all, if I have no desire that you finish your novel or that our friendship continues, I am indifferent to these things, I don't care that they are so. Therefore, one has faith that $\mathrm{p}$ only if one has some desire for p's truth.

We might resist. True enough, when we care that $\mathrm{p}$ we typically want $\mathrm{p}$ to be the case; but there are exceptions. Imagine a meth addict who has no desire whatsoever to stop but who, upon coming to recognize how much better his life might be if he were to stop, wants to want to stop. In that case, if he's disposed to do something about changing his first-order desire and his behavior, then, even if he has so far failed, he is not completely indifferent to stopping, he cares at least somewhat that he stops. ${ }^{6}$

Notice that the first- and second-order desire cases share something in common: having a desire in virtue of which one cares that $\mathrm{p}$. Might one have a desire in virtue of which one cares that $\mathrm{p}$ without having a first- or higher-order desire for $\mathrm{p}$ ? Imagine a young mother battling a recurrence of breast cancer; she has no first- or higher-order desire to live due to the depression-inducing side-effects of the treatment. Nevertheless, she cares that she survives since she considers her survival desirable for the sake of her children and she longs for them to flourish. If this is possible, then one can have faith that $\mathrm{p}$ while having no first- or higher-order desire for p's truth. Rather, what's required is a desire in virtue of which one cares that $\mathrm{p}$.

Here's a second argument. Like other complex propositional attitudes, e.g. fear and hope, faith motivates behavior. In the case of fear, this is indicated by the fact that all you need to know to understand why the hiker is beating the grass as she walks through the meadow is that she fears rattlesnakes lie nearby. In the case of hope, it's indicated by the fact that all you need to know to understand why the climber is waving toward the sky is that he hopes to catch the eye of the search-and-rescue pilot. Fear and hope have built in to them what it takes to motivate behavior; that's why they explain it. The same goes for faith. All you need to know to understand why David continues to study Torah 
despite his doubts is that he has faith that the basic Jewish story is true. All you need to know to understand why a couple seeks marital counseling is that they have faith that they can work things out. Like fear and hope, faith motivates behavior; that's why it explains it. But cognition alone cannot motivate behavior; desire is required. Like fear and hope, therefore, faith has desire built into it.

Third: One can have faith that $\mathrm{p}$ only if one has a tendency to feel disappointment upon learning that not-p. But if one has a tendency to feel disappointment upon learning that not-p, then one cares that $\mathrm{p}$. However, if one cares that $\mathrm{p}$, one desires p's truth, or at least has a desire in virtue of which one cares. So one can have faith that p only if one has a desire in virtue of which one cares that $\mathrm{p}$.

If any of these considerations are on target, then, even if one can have faith that $p$ without desire for the truth of $\mathrm{p}$, one cannot have faith that $\mathrm{p}$ without a desire in virtue of which one cares that p. Different sorts of desires may well satisfy that description, so I'll gather them under the rubric of a positive conative orientation, and say that faith that $\mathrm{p}$ requires a positive conative orientation toward p. My first complaint about Schellenberg's account of faith, then, is that in addition to a positive evaluation of $p$, which he recognizes, faith requires a positive conative orientation toward $\mathrm{p}$ as well.

\section{Faith and belief}

A very brief word about belief is in order. As Schellenberg thinks of it, to believe that $\mathrm{p}$ is to be 'disposed to apprehend the state of affairs reported by $\mathrm{p}$, when that state of affairs comes to mind, under the concept reality'. ${ }^{7}$ Note that, according to Schellenberg, belief is a dispositional state, neither a feeling nor a disposition to a feeling, and is ungraded, i.e. doesn't come in degrees. In what follows, I will assume he is right.

According to Schellenberg, propositional faith 'is positively incompatible with belief'. ${ }^{8}$ That is, one cannot have faith that $\mathrm{p}$ so long as one believes that $\mathrm{p}$. This claim is startling, to say the least.

Two initial concerns. First, oddly enough, this claim is not implied by his account. For on his account, $S$ has faith that p only if '(1) S lacks evidence causally sufficient to believe that p'. But one can lack evidence causally sufficient to believe and yet believe. 
Since no other condition in his account implies that propositional faith precludes belief, it leaves the door open to their compatibility.

Second, even if condition (1) is amended so that it shuts the door on belief - e.g. if it were to say, 'S has faith that p only if (1) S lacks belief that p' - the account still allows one to have faith that $\mathrm{p}$ when one does not believe that $\mathrm{p}$ but rather believes that $i t$ is very likely that $p$. But surely Schellenberg is not concerned to insist that although faith that $\mathrm{p}$ is incompatible with belief that $p$, it's right at home with believing that it is very likely that $p$. Condition (1) must be amended to rule out certain probabilistic beliefs.

Suppose these concerns can be resolved. Still, the idea that faith that $\mathrm{p}$ is incompatible with belief that $\mathrm{p}$ is flat-out shocking, especially in light of the natural home of faith-talk in Western religion, notably Christianity. There we find billions of people who say that they have faith that, for example, Jesus rose from the dead, and that their faith is partially constituted by belief that Jesus rose from the dead. Why should we suppose their self-ascription could not possibly be right?

In a word, answers Schellenberg, voluntariness. Whatever else we say of faith, he writes, it 'must be understood as voluntary'. He continues:

Three important intuitions...need to be captured by any understanding of the concept of faith's voluntariness. These might be informally expressed as follows: if you want it, you can have it; if you have it but don't want it, you can drop it; and you shouldn't expect to keep it without doing something about it. In other words, faith is accessible to, and can be produced by, anyone who seeks to have it...; it can be got rid of, terminated by those who no longer wish to have it...; and it is vulnerable and will be lost in the absence of sustaining activity....

Moreover, he writes,

[T]he link between faith (or its absence) and our actions is direct: it is not just that how we live may over time have some influence on whether we have faith or lack it but rather that, if I try, I can have (or lose) faith right now through an act of will and that without such exertion faith will definitely be lost. ${ }^{10}$ 
In support of faith's necessary voluntariness, Schellenberg says that it follows from the fact that faith can be a virtue and meritorious, and he insightfully discusses many cases in which faith-talk appears to presuppose voluntariness. ${ }^{11}$

Before I assess Schellenberg's defence of the incompatibility of faith and belief, I want to make one remark about the degree to which faith is voluntary. According to Schellenberg, 'faith...can be produced by anyone who seeks to have it', 'right now through an act of will'. This seems false to me. For although faith can be produced through an act of will by some of those who seek to have it, it is false that faith can be produced through an act of will by just anyone who seeks to have it. For one can have faith that $\mathrm{p}$ only if one considers it to be good or desirable. But those who do not now consider $\mathrm{p}$ to be good or desirable cannot bring it about just by an act of will that they consider it to be good or desirable. Therefore, if we don't now regard p as good or desirable, then, even if we seek to have faith that $\mathrm{p}$, we cannot produce faith that $\mathrm{p}$ just by an act of will. (Mutatis mutandis, the same goes for what he says about sustaining and terminating faith.) Faith is not nearly as voluntary as Schellenberg says it is.

Now to his defence of the incompatibility of faith and belief. Here is the relevant passage:

Perhaps our favorable evaluation plus voluntary assent represents one way of instantiating [propositional faith] and [our favorable evaluation plus] belief another... But to see that this claim is false, we need only consult more carefully our definition of voluntariness in faith.... Belief obviously cannot be intentionally produced, but...neither can it be intentionally sustained or forsaken.... Hence it cannot represent so much as one way for propositional faith to be instantiated. ${ }^{12}$

The argument here can be expressed in different idioms Schellenberg deploys in the text. For example: belief cannot partly constitute faith since faith is voluntary and belief is not. Alternatively: belief cannot partly constitute faith since faith is produced, sustained, and forsaken just through an act of will and belief is not. Or, as in the passage before us: belief cannot partly constitute faith since faith is intentionally produced, sustained, and 
forsaken and belief is not. I choose the 'just through an act of will' idiom and I will focus on producing faith.

I have four points to make.

First, Schellenberg's argument implicitly contains the conditional premise that if faith that $\mathrm{p}$ is produced by an act of will and belief that $\mathrm{p}$ is not, then belief that $\mathrm{p}$ cannot partly constitute faith that $\mathrm{p}$. This seems false to me. For faith has multiple constituents, and even if some of them cannot be produced just by an act of will, faith itself might still be produced just by an act of will, provided that some others can be so produced. Indeed, on Schellenberg's own account, that's what faith is like. S has faith that $\mathrm{p}$, he says, only if $\mathrm{S}$, just through an act of will, adopts a policy of assent toward $\mathrm{p}-$ never mind that $\mathrm{S}$ cannot, just through an act of will, consider $\mathrm{p}$ to be good or desirable, and never mind that $\mathrm{S}$ cannot, just through an act of will, tenaciously and persistently represent the world to herself as including the state of affairs reported by p. Applying the point to belief: even if faith that $\mathrm{p}$ is partly constituted by belief that $\mathrm{p}$ and belief cannot be produced just by an act of will, faith that $\mathrm{p}$ might still be produced just by an act of will.

Second, there seem to be many ways in which propositional faith can be realized, and some of them need not feature any component that was produced by an act of will. For example, I consider it to be desirable that my sons flourish well into adulthood and I care deeply that they do so; and despite the current pubescent evidence to the contrary, I still believe that it's likely they will do so. Consequently, I am strongly disposed to act in various ways appropriate to my positive evaluation, care, and belief, e.g. I'm strongly disposed to give of myself toward their flourishing in adulthood should they seek my assistance, I'm strongly disposed to write their spouses and children into my will should they marry or become parents, and so on. Indeed, I am committed to act in these ways. In that case, I would think, I have faith that they will flourish, even though none of these mental items needs to have been produced just by an act of will.

Third, we sometimes talk as though faith is involuntary. For example, some people report finding propositional faith within themselves, as if it were a natural gift bestowed upon them. Others say that they have always had faith that certain things are so, as if from their mother's milk. Still others say they went to sleep with a faith besieged by 
doubts and awoke to find that it had vanished in the night. Such talk suggests that faith is sometimes not produced, sustained, or forsaken just by an act of will.

Fourth, one might argue that if faith is involuntary - that is, if there is an instance of faith that something is so and it is not produced just by an act of will - it can be neither virtuous nor meritorious; but since it can be both, it is voluntary. This line of thought is mistaken. An instance of faith can be virtuous - that is, it can exhibit an excellence without being produced by an act of will, just as an instance of open-mindedness or humility can be virtuous without being produced by an act of will. Moreover, faith can be meritorious without being produced by an act of will. For example, one's faith can be meritorious if it is produced by the collective effect of many acts of will on one's part over a long period of time, no one of which sufficed. And one's involuntarily acquired faith can be meritorious, at least to some extent, if one is able both to do and to refrain from doing things that one knows will increase or decrease the chances that it will be sustained or forsaken.

On the basis of these four points, I conclude that faith that $\mathrm{p}$ does not require voluntariness and it is compatible with belief that $\mathrm{p}$.

\section{Faith and doubt}

According to Schellenberg, S has faith that p only if '(4) S voluntarily and committedly adopts a policy of assent...toward p'. Schellenberg's commentary on this requirement makes it clear that he sees 'assent as part of faith that p,' indeed, a necessary

part. ${ }^{13}$ But it doesn't imply assent. That's because, in general, one can committedly adopt a policy to do something and yet not do it. Suppose we rectify this omission: $\mathrm{S}$ has faith that $\mathrm{p}$ only if $\mathrm{S}$ voluntarily assents to $\mathrm{p}$.

Now, assent is a mental act; as such, it lasts about as a long as a handshake. This is why Schellenberg introduces adopting a policy of assent toward p. '[T]he main idea', he writes, 'is that of some ongoing positive mental response' to the object of assent. ${ }^{14}$ And:

By speaking of a "policy," I mainly hope to communicate that we are talking about something intended to continue at least for a time; something more than 
simply a single action or series of actions that leaves no cognitive residue. Indeed, if these policies are successfully implemented, what we really have is something like a disposition, though one intentionally initiated and sustained, to respond with assent to an imagined state of affairs. ${ }^{15}$

Talk of a 'policy,' therefore, is meant to suggest something mental 'intended to continue for a time,' a 'cognitive residue,' 'something like a disposition'. The just-quoted passage also reveals how Schellenberg is thinking of adopting a policy of assent: it is to intend to assent to $\mathrm{p}$ when it comes to mind. This intention may 'be of shorter or longer duration'; in the latter case it constitutes 'a long-term commitment'. ${ }^{16}$

But what about assent itself? Among other things, he says that what he has in mind can also be expressed by 'affirming', 'judging', 'taking to be true', and 'resolving to think as true'. ${ }^{17}$ Moreover, he says that assent is what is withheld when one 'withholds judgment' on a proposition, and he suggests that 'we think [of not withholding judgment] in terms of taking sides, identifying oneself with one side or the other of the issue, deciding in favour of the truth of $\mathrm{p}$ or the truth of not-p' ${ }^{18}$ In this connection, he writes:

[i]n judging, one is consciously aware of the options and mentally plumps for one or the other. "Judgment" has at least a connotation of finality; the mental judgment that $\mathrm{p}$ or that not-p...involves putting behind one the issue of p's truth and also the alternative judgment. ${ }^{19}$

Furthermore, what he means by 'assent' can be seen in the previously mentioned case of the runner who, after forming a mental picture of himself placing well in the race, 'mentally affirms over and over that it corresponds to the way things are'. ${ }^{20}$ So, according to Schellenberg, to assent to $\mathrm{p}$ involves, among other things, judging $\mathrm{p}$ to be true with finality, deciding in favour of its truth, putting behind one the issue of its truth, taking it to be true, resolving to think of it as true, and affirming that it corresponds to the way things are. Call this Schellenbergian assent.

Now to my complaints: they number two. 
First, recall that Schellenberg aims to develop an account of propositional faith according to which faith that p can sit well with being in doubt about p. Unfortunately, his account does not achieve this aim. For, on his account, one has faith that $\mathrm{p}$ only if one gives Schellenbergian assent to it. But giving Schellenbergian assent to $\mathrm{p}$ does not sit well with being in doubt about it. That's because for one to be in doubt about $\mathrm{p}$ is for one to have what appear to one to be no better grounds to believe $\mathrm{p}$ than not-p and, as a result, to be inclined neither to believe p nor not-p. And being in that state is at odds with judging $\mathrm{p}$ to be true with finality; moreover, it is at odds with Schellenberg's other characterizations of assent noted above.

Second, recall also that he aims to develop an account according to which a religious agnostic can possess an epistemically responsible and epistemically virtuous religious faith, one that can ground a religious way of life. Unfortunately, this aim too is unachievable on his account. That's because the religious agnostic is in doubt about whether there is a God, or, more generally, about the truth of what Schellenberg calls ultimism, the proposition that there is a metaphysically and axiologically ultimate reality in relation to which our greatest good can be attained. ${ }^{21}$ But just as believing theism or ultimism while being in doubt about them is not epistemically responsible or epistemically virtuous, so is giving them Schellenbergian assent while being in doubt about them. For, among other things, Schellenbergian assent involves judging with finality; but it is not epistemically responsible or epistemically virtuous for one to judge with finality that $\mathrm{p}$ when one is in doubt about it. And the same goes for Schellenberg's other characterizations of assent noted above.

I conclude that given Schellenberg's account, faith that $\mathrm{p}$ is at odds with being in doubt about p. Consequently, a religious agnostic cannot have an epistemically responsible and epistemically virtuous religious faith.

\section{Sketch of an alternative account of propositional faith}

In what follows, I sketch an account that avoids the difficulties that beset Schellenberg's account and achieves his aims. I say 'sketch'. Much-needed development, emendation, and qualification must wait for another occasion. 
Faith that $\mathrm{p}$ is a complex propositional attitude consisting of (i) a positive evaluation of $p$, i.e. considering $p$ to be good or worthy of desire, (ii) a positive conative orientation toward p, and (iii) a positive cognitive stance toward p, all under the condition of not regarding oneself as optimally positioned vis-à-vis p's truth. ${ }^{22}$ Although nothing can be faith without (i)-(iii), different items can stand in for each of (i)-(iii). Belief that $\mathrm{p}$ and Schellenbergian assent toward $\mathrm{p}$ can stand in for the positive cognitive stance required by faith that $\mathrm{p}$. A desire for $\mathrm{p}$ can stand in for the positive conative orientation toward $\mathrm{p}$, as can a higher-order desire for $\mathrm{p}$ and even a mere desire related to $\mathrm{p}$, related in such a way that in virtue of having that desire, one cares that $\mathrm{p}$. And a variety of positive cognitive stances can stand in for 'considering' $p$ to be good or desirable, the positive evaluation of $\mathrm{p}$.

It would be a mistake, however, to infer that faith that $\mathrm{p}$ requires either belief that $\mathrm{p}$ or Schellenbergian assent to $\mathrm{p}$; faith that $\mathrm{p}$ can sit well with being in doubt about $\mathrm{p}$, but both of them are at odds with being in doubt. So, then, what might stand in for the positive cognitive stance required by faith while sitting well with being in doubt?

To begin to answer that question, consider the following three very short stories. Northbound. It's May 6, 2010. I'm at the southern terminus of the Pacific Crest Trail, the Mexican border with California. After some goodbyes, I start to walk to Canada, 2,655 miles north. A lot can go wrong in 2,655 miles. Most nights, after two dozen up-and-down miles in the sun, I'm beat. Now, nearly four weeks and 500 miles later, I'm terribly homesick. Do I believe I won't make it to Canada? Not at all. I feel stronger every day; trail camaraderie is pleasurable, as is meeting demanding daily goals; and the beauty of the high desert in Spring is astounding. Moreover, my family is planning a rendezvous. Besides, what better way to express gratitude at midlife than a walk from Mexico to Canada? So then, do I believe I will make it? Not at all. A lot can go wrong in 2,155 miles. Indeed, given what evidence I've got to go on, I can't even hazard a guess as to how likely it is that I will. Nevertheless, each morning I picture Monument 78 at the Canadian border just north of Hart's Pass with me standing next to it smiling broadly, and I head north on the assumption that come September, that picture will be reality. 
Captain Morgan. On the trail, there's a saying about the relationship between a sleeping trailside rattlesnake and a group of hikers passing by: the first wakes it up, the second pisses it off, and the third gets bit. I was the third. Fortunately for me, this unseen rattler, coiled deep in the sand under some scrub, did not bite me. Captain Morgan was not so fortunate. It's dusk and four paces behind me he speaks of his new right hip and shoulder, replacements for the ones he lost to a bomb in Iraq nine months earlier. He tells me how he aims to continue his recovery on his walk to Canada, when-all of a sudden - he stops and says matter-of-factly, "It bit me. It didn't even rattle," pointing to a 40-inch Mojave Green, silent and still. We inspect his wound. I dial 911; no reception. Twenty minutes later, at Tyler Horse Creek, he's calm with no symptoms. Rattlesnakes control envenomation, sometimes delivering 'dry bites' to animals too large to eat; moreover, a snake's timing can be off so that it releases its venom before sinking its fangs. Maybe Captain got lucky. The next morning he says he feels fine, so the other hikers congregated at the creek move on. I stay. Thirty minutes later, he heaves up his breakfast and continues to wretch every two minutes or so; he quickly becomes weak and feverish, breathing with difficulty; signs of delirium appear. ${ }^{23} \mathrm{He}$ needs help...fast. But which way should he go? Should he backtrack 24 miles to Highway 138, or forge ahead 24 miles to Highway 58? Our maps give us no reason to prefer either route. Three miles ahead, there's a two-mile side-trail to a trailhead; might we find a vehicle to hotwire at midweek? Five miles back there's a dirt road into the hills; might it lead to a home? Maybe he should stay put at the creek, the only sure source of water in this 48-mile stretch; perhaps a hiker with a working phone will arrive and we can call in an airlift. Time is short; he needs to decide. He rules out staying put, and decides that moving ahead is better than going back. So he stumbles forward on the assumption that help lies ahead.

Eliotwright. In an insightful autobiographical essay, William Wainwright characterizes his stance toward God as one filtered through a "congenital skepticism" that renders it difficult for him "to embrace any controversial [proposition] without some hesitation". ${ }^{24}$ Nevertheless, he writes, "classical theistic metaphysics" has come to seem "more reasonable to me, on the whole, than its alternatives" and it "survives criticism at least as well as, and probably better than, its competitors". ${ }^{25}$ Moreover, sensitive to what 
he describes as the frailty of "human effort, thought, and ideals when confronted by what [Paul] Tillich called the threat of death, meaninglessness, and sin," he has long been attracted to what the Christian story has to say about these matters. In light of these and other considerations, he says that "even if Christian theism isn't more probable than not, it is still reasonable to embrace it" since, by his lights, it best addresses the whole of human experience and the evidence favors it over its competitors. ${ }^{26} \mathrm{He}$ concludes the essay with this paragraph:

My attitude is in many ways similar to T.S. Eliot's. Eliot appears to have combined a deeply serious faith with both irony and skepticism. (When asked why he accepted Christianity, he said he did so because it was the least false of the options open to him.)... I do not regard my stance as exemplary. If Christianity (or indeed any form of traditional theism) is true, a faith free from doubt is surely better. I suspect, however, that my religious life may be fairly representative of the lives of many intelligent, educated, and sincere Christians in the latter part of the twentieth century. ${ }^{27}$

In personal correspondence, Wainwright indicates that he himself thinks Christianity is more likely than not. Eliot, however, is a different story. He thinks Christianity is "the least false" of the credible options, which suggests that by his lights it is more likely than each of the non-Christian options but less likely than their disjunction. Imagine, then, someone like Wainwright but with Eliot's cognitive stance. Call him Eliotwright.

Five observations about the protagonists in our stories are pertinent.

First, each has faith. I have faith that I will make it to Canada; Captain Morgan has faith that help lies ahead; Eliotwright has faith that the basic Christian story is true.

Second, none of us believes these things. Recall that, according to Schellenberg, to believe that $\mathrm{p}$ is to be 'disposed to apprehend the state of affairs reported by $\mathrm{p}$, when that state of affairs comes to mind, under the concept reality. ${ }^{28}$ We have no such disposition. Nor do we give Schellenbergian assent to these things; and we do not intend to give Schellenbergian assent to them whenever we bring them to mind.

Third, each of us is in doubt about the object of his faith. I think that what I've got to go on puts me in no position to say whether I'll make it to Canada, not even how likely it is. Captain Morgan thinks staying put has the least going for it, and that moving 
forward is slightly better than backtracking. Eliotwright thinks Christianity is the least false of the credible options, which suggests he deems his evidence for Christianity to be no better than the evidence for the disjunction of non-Christian options.

Fourth, despite our lack of belief and Schellenbergian assent, and despite our (at best) being in doubt, each of us acts on a certain assumption. I act on the assumption that I will make it to Canada. Captain acts on the assumption that help lies ahead. Eliotwright acts on the assumption that the basic Christian story is true. The account on offers takes with utmost ontological seriousness the surface grammar of our attributions here. There really is something each of us acts on, namely an assumption.

Fifth, in virtue of our assumptions, each of us behaves in appropriate ways. I assume I will make it to Canada, and so I pick up camp each morning and head north, scheduling resupplies, planning family rendezvouses, making reservations at Manning Park Lodge and the like. Captain Morgan assumes help lies ahead, and so he rises from his knees, slings his pack onto his back, and staggers forward. Eliotwright assumes the basic Christian story is true, and so he makes weekly confession, receives the sacraments, and gives thanks to the Lord.

My proposal, then, is this: there is such a thing as belief-less and Schellenbergianassent-less assuming; it can stand in for the positive cognitive stance required by faith; and, when it does, the result is a faith that sits well with being in doubt about its propositional object. If upon further inquiry this proposal proves viable, the prospects improve significantly for the exciting possibility Schellenberg envisions: that of an epistemically responsible and epistemically virtuous religious agnostic who, despite

being in doubt, possesses a religious faith that grounds a religious way of life. ${ }^{29,30}$

\section{References}

ALSTON, WILLIAM P. (1996) 'Belief, Acceptance, and Religious Faith', in J. Jordan and D. Howard-Snyder (eds), Faith, Freedom, and Rationality (Lanham MD: Rowman \& Littlefield), 3-27.

CHIGNELL, ANDREW. (2013) 'Prolegomena to any future non-doxastic religion', Religious Studies 48, xx-xx. 
HOWARD-SNYDER, DANIEL. (2013) 'Propositional Faith', American Philosophical Quarterly, xxx-xxx.

SCHELLENBERG, J. L. (2005) Prolegomena to a Philosophy of Religion (Ithaca NY: Cornell University Press). (2007) The Wisdom to Doubt: A Justification of Religious Skepticism (Ithaca NY: Cornell University Press). (2009) The Will to Imagine: A Justification of Skeptical Religion (Ithaca NY: Cornell University Press). (2013) 'Reply to my critics', Religious Studies 48, xxx-xxx.

WAINWRIGHT, WILLIAM. (1994) 'Skepticism, Romanticism, and Faith', in T. Morris (ed) God and the Philosophers (New York: Oxford University Press), 77-87.

\section{Notes}

${ }^{1}$ I will focus on the account developed in Schellenberg (2005).

${ }^{2}$ Ibid., 129-130.

${ }^{3}$ Ibid., 138-139, slightly altered.

${ }^{4}$ Ibid., 133.

${ }^{5}$ Ibid., 133.

${ }^{6}$ Thanks to John Schellenberg and Terence Cuneo for the objection.

${ }^{7}$ Ibid., 50-51. For more on Schellenberg on belief, see Schellenberg (2005), chapter 2; Chignell (2013); and Schellenberg (2013), xxx-xxx.

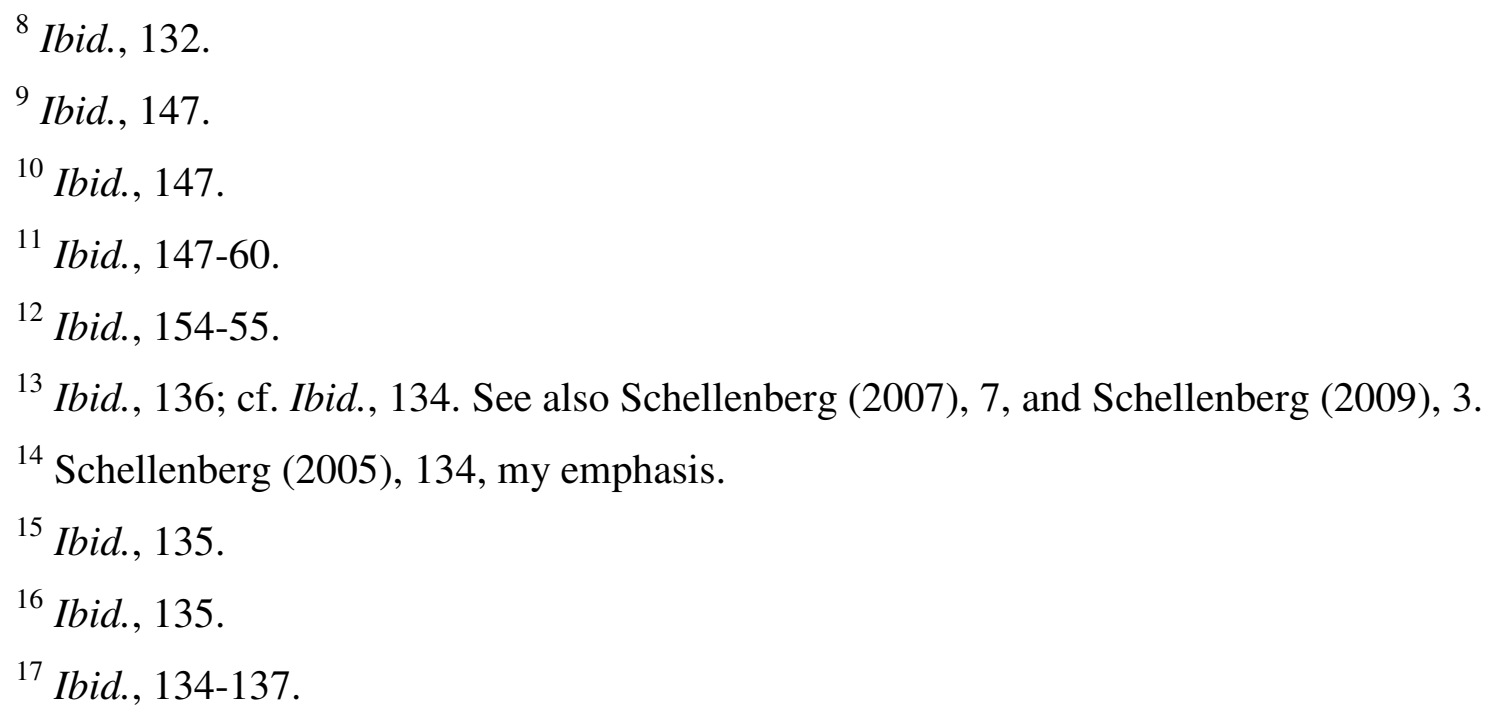


${ }^{18}$ Ibid., 103.

${ }^{19}$ Ibid., 103.

${ }^{20}$ Ibid., 130.

21 Ibid., 37.

${ }^{22}$ For we rightly contrast the cognitive stance implicit in faith with that of sight and knowledge. Moreover, the closer someone verges on what we regard as epistemic optimality vis-à-vis p's truth, the more we hesitate to attribute faith to them. Finally, if faith requires that one not regard oneself as optimally positioned, we can explain two curious facts: you can't have faith that you exist, and a fully omniscient, cognitively unsurpassable God can't have faith at all.

${ }^{23}$ According to Wikipedia: “C. scutulatus is widely regarded as producing one of the most toxic snake venoms in the New World.... In people bitten by Venom A Mojave rattlesnakes (those outside the relatively small Venom B area in south-central Arizona), the onset of serious signs and symptoms can be delayed, sometimes leading to an initial underestimation of the severity of the bite. Significant envenomation...can produce vision abnormalities and difficulty swallowing and speaking. In severe cases, skeletal muscle weakness can lead to difficulty breathing and even respiratory failure".

${ }^{24}$ William J. Wainwright, "Skepticism, Romanticism, and Faith," in Thomas V. Morris (ed), God and the Philosophers (New York: Oxford University Press, 1994), 78.

25 Ibid., 78.

${ }^{26}$ Ibid., 80.

27 Ibid., 87.

${ }^{28}$ Schellenberg (2005), 49-50.

${ }^{29}$ I develop this proposal in (Howard-Snyder 2013).

${ }^{30}$ For valuable input, many thanks to William Alston, Robert Audi, Nathan Ballantyne, Andrew Chignell, Tom Crisp, Jeanine Diller, Andrew Dole, Frances Howard-Snyder, Hud Hudson, Steve Layman, Gerald Marsh, Wes Morriston, Michael Rea, John Schellenberg, William Wainwright, and Dennis Whitcomb. 